Fikrah: Jurnal Ilmu Aqidah dan Studi Keagamaan

issn 2354-6147 eissn 2476-9649

Tersedia online di: journal.stainkudus.ac.id/index.php/Fikrah

DOI: http://dx.doi.org/10.21043/fikrah.v4i2.2083

\title{
Menanamkan Toleransi Multi Agama sebagai Payung Anti Radikalisme (Studi Kasus Komunitas Lintas Agama dan Kepercayaan di Pantura Tali Akrab)
}

\author{
Kholidia Efining Mutiara \\ STAIN Kudus, Indonesia \\ kholidiaeveningmutiara19@gmail.com
}

\begin{abstract}
Abstrak
Artikel ini bertujuan untuk melihat Indonesia yang merupakan salah satu negara yang multi agama yakni banyak ragam keyakinan dan kepercayaan di dalamnya, akan tetapi dari perbedaan agama tersebut dapat pula memunculkan tindakan radikalisme. Oleh karena itu penanaman toleransi perlu ditekankan padasetiapindividu, sebagaimana yang sudah diterapkan pada komunitas lintas agama pantura. Penelitian ini menggunakan pendekatan studi kasus di komunitas lintas agama dan kepercayaan pantura, yang dikenal tali akrab, yakni salah satu komunitas persahabatan berbagai agama di wilayah pantura Indonesia. Adapun temuan penting pada tulisan ini, mengenai jalan keluar dalam menanamkan toleransi multi agama sebagai payung anti radikalisme di masyarakat, dengan mendiskusikan permasalahan masing-masing agama secara bersama tanpa melihat perbedaan dalam keimanam.
\end{abstract}

Kata kunci: Keimanan, masyarakat, multi agama, radikalisme,toleransi 


\begin{abstract}
This article specifically aims at describing Indonesia as one of the multireligious country having a lot of various confidence and trust, but from the religious differences is able to bring about actions of radicalism. Therefore, tolerance maintenances need to emphasize to every individual, as we have already applied to the interfaith community of PANTURA. This study used a case study approach in inter-religious and belief communities of PANTURA, known as TALI AKRAB, which is one of the various religious friendship communities in the northern coasts (PANTURA) of Indonesia. The main findings in this paper include the way of instilling a multi-religious tolerance as a tool of avoiding radicalism in society, by discussing the problems of each religion and ignoring differences in the faith.
\end{abstract}

Keywords: Faith, Community, Multi-religion, Radicalism, Tolerance

\title{
Pendahuluan
}

Dalam UUD No. 40 tahun 2008 tentang penghapusan Diskriminasi Ras dan etnis pasal 1 (2) Ras adalah golongan bangsa bedasarkan ciri-ciri fisik dan garis keturunan, (3) etnis adalah penggolongan manusia bedasarkan kepercayaan, nilai, kebiasaan, adat istiadat, norma bahasa, sejarah, geografis, dan hubungan kekerabatan. Selain itu, pada pasal 22 (1) setiap orang bebas memeluk agamanya masing-masing dan untuk beribadah menurut agama dan kepercayaannya. Hal ini tergambar jelas, bahwa Indonesia mengakui keragaman agama dan pernyataan untuk melakukan pendiskriminasian antara satu agama dan agama lain. Akan tetapi yang terjadi, perbedaan keyakinan sering dijadikan dalih dalam melakukan tindakan-tindakan radikal, sebagai contoh adalah kasus Ambon dan Maluku yang menelan ribuan korban jiwa, dimana hal itu mencerminkan terjadinya konflik social antar agama dan suku secara berhimpitan.

Kekerasan demi kekerasan bergulir silih berganti, yang bermula dari persoalan konflik vertical namun kemudian merembet ke persoalan horizontal, konflik ini mewujud dalam bentuk konflik antar etnis dan antar agama. Di poso, Sulawesi Tengah, Konflik yang dimulai dari perkelahian antar warga berubah menjadi konflik antar komunitas agama Islam dan Kristen (Moesa, 2007, hal. 4). Oleh karena itu, perlu kiranya menanamkan sikap toleran terhadap agama lain. Penelitian ini secara khusus memotret bagaimanakan bentuk toleransi beragama pada komunitas lintas agama dan kepercayaan di pantura (Tali Akrab), dan bagaimanakah menanamkan jiwa toleransi multi agama anti radikalisme.

Penelitian ini merupakan jenis penelitian kualitatif, yakni menekankan sikap realita yang terbangun secara sosial, hubungan erat antara peneliti dan subjek yang diteliti, serta tekanan situasi yang membentuk penyelidikan (Norman dan Yvonna, 2009, hal. 6), pada penelitian ini peneliti lebih menitik beratkan pada kualitas hasil 
penelitian yaitu penelitian yang mendalam pada permasalahan dan penyelesaian. Dalam proses penelitian penulis menggunakan observasi partisipatoris dan penelitian pustaka (Lybrary Research) yakni jenis penelitian yang dilakukan dengan menggunakan literatur (kepustakaan) baik berupa buku, catatan, maupun laporan hasil penelitian dari peneliti terdahulu (Hasan, 2004, hal. 5).

Sifat penelitian yang dilakukan oleh peneliti bersifat mendalam, yaitu implikasi dalam Menanamkan Toleransi Multi Agama sebagai Payung Anti Radikalisme. Adapun Studi Kasus pada penelitian ini ialah Komunitas Lintas Agama dan Kepercayaan di Pantura / Tali Akrab pada tahun 2016. Dilihat dari segi analisisnya, penelitian ini bersifat kualitatif, yaitu mendalam pada permasalahan serta mencari solusi dalam permasalahan, selain itu data yang di sajikan dalam bentuk verbal dan bukan bentuk angka (Sutrisno Hadi, 1993, hal. 43). Penelitian ini menggunakan pendekatan Observasi partisipatoris yakni peneliti ikut serta/ terjun langsung dalam pengamatan, bukan sekadar pengamatan jarak jauh. Menggunakan observasi partisipatoris kegiatan yang terjadi tentu amat jelas untuk peneliti amati. Selain itu moment pada komunitas yang peneliti amati tidak hanya sekali, melainkan beberapa kali yakni sejak tahun 2014 hingga tahun 2016. Selain observasi partisipatoris, peneliti juga menggunakan penelitian pustaka dimana beberapa literatur di gunakan sebagai data pendukung untuk penelitian ini seperti metode, teori,atau opini. Sedangkan untuk analisa data dalam hal ini penulis menggunakan analisis non statistik, artinya data yang ada di analisis menurut isinya, karena itu analisis semacam ini di sebut analisis contect (contect analisis) (Mustaqim, 2007, hal. 13).

Pada tulisan ini terdapat kesamaan dan perbedaan pada buku M. Aziz Tunny, Dkk. Dalam bukunya yang berjudul "Wajah agama di media", pada buku tersebut lebih menitik beratkan pada wajah pluralisme beragama dalam media. Sedangkan pada tulisan ini lebih menitik beratkan terhadap penanaman Toleransi beragama pada kehidupan bermasyarakat. Adapun titik persamaan buku M. Aziz Tunny, Dkk. Dengan mini riset ini terdapat pada pembahasan yang mengkritisi toleransi multi agama. Sementara itu, temuan penting pada tulisan ini mengenai jalan keluar dalam Menanamkan Toleransi Multi Agama sebagai Payung Anti Radikalisme pada Masyarakat, hal ini akan di kaji menggunakan pendekatan Studi Kasus di Komunitas Lintas Agama dan Kepercayaan Pantura (Tali Akrab), yakni salah satu komunitas persahabatan berbagai agama di wilayah Pantura Indonesia.

\section{Makna Toleransi Beragama}

Secara harfiyah kata 'Toleran' bermakna sikap menenggang (menghargai, membiarkan, membolehkan) pendirian ( pendapat, pandangan, kepercayaan, kebiasaan, kelakuan, dsb.) seseorang yang berbeda atau bertentangan dengan pendirian sendiri. Adapun kata 'toleransi' bermakna sikap atau sifat toleran. Modal dasar memupuk sikap toleransi antarsesama dalam kehidupan sosial (Rosyid, 2016, hal.76). 
Dari pemaparan diatas, dapat ditarik sebuah kesimpulan bahwa toleransi beragama merupakan sikap saling menghargai antar keyakinan/ agama yang berbeda. Sebagaimana yang tercantum pada Surah Al-kafirun ayat 6, yang berbunyi, "Agamamu adalah agamamu, Agamaku adalah Agamaku".

Berdasarkan ayat diatas, tentu sedikit banyak kita memahami, bahwa agama yang dianut seseorang tidak seharusnya dipaksakan untuk diikuti, akan tetapi kebebasan berkeyakinan adalah hak setiap individu. Di dalam ayat diatas terkandung makna untuk bersikap fanatik terhadap agama kita sendiri dan bartoleransi terhadap agama lain.

Agama merupakan pegangan utama dalam melangsungkan kehidupan, karena pegangan utama inilah setiap individu memang seharusnya memegang teguh agama tersebut untuk kelangsungan hidupnya atau dalam istilah lain adalah fanatisme, yang tentunya berimbas pada dirinya sendiri, akan tetapi bukan berarti kita memegang teguh keyakinan yang kita miliki kemudian mengaggap agama lain adalah salah atau sesat. Apabila kita mengacu kepada konteks fanatisme beragama hal tersebut benar, akan tetapi apabila yang kita hadapi adalah konteks toleransi beragama, tentu hal tersebut tidaklah benar. Jadi dapat di simpulkan sebagaimana yang disampaikan Thodorson dan Theodorson dalam bukunya sebagaimana dikutip Musdah Mulia (2010), bahwa agama itu, bersifat sungguh-sungguh pribadi dan sungguh-sungguh sosial.

Manusia hidup tentu membutuhkan orang lain atau dalam istilah lain Zoon Politicon oleh karena itu sikap toleransi harus ada pada tiap individu, apalagi soal keyakinan, dimana setiap orang berhak menentukan apa keyakinannya, tidak perlu bagi kita untuk menyalahkan keyakinan yang dianut orang tersebut. spabila kita pahami, faktor pemicu konflik antar dan intern umat beragama, diantaranya adalah ; a) berupa pemahaman yang dangkal, fanatic, dan tekstual terhadap ajaran agamanya, berdampak memandang sempit pemeluk agama lain; b) adanya loko penggerak untuk menyelesaikan probem perbedaan antar agama dengan konflik; Konflik sebagai pelampiasan atas keterbatasan penuhi kebutuhan hidup bagi pelaku karena factor sumber hidup, kemiskinan, dan disharmoni social. Interaksi social positif tercipta bila harmoni social dan empati social tercipta juga terantisipasi sikap agresif (Mulia, 2010, hal. 77).

\section{Anti Radikalisme}

Gerakan perlindungan dan pemajuan hak-hak asasi manusia secara internasional dimulai dengan Deklarasi Universal Hak Asasi Manusia (Universal Declaration of Human Right) disingkat DUHAM oleh siding Umum Perserikatan Bangsa-Bangsa (PBB) pada januari 1948. DUHAM menerangkan hak-hak yang seharusnya dimiliki manusia tanpa membedakan jenis kelamin, gender, agama, dan ikatan primodial lainnya. Tujuan pokok deklarasi tersebut adalah meningkatkan martabat dan kesejahteraan umat manusia. 
Pada persoalan agama yang nyata dalam kebebasan tiap orang dalam memilih keyakinan. Agama memberikan perhatian bukan hanya pada perkara mudah bahkan pada kondisi yang amat sulit sekalipun untuk semua orang di sepanjang waktu, tanpa memandang usia, jenis kelamin, atau status di dalam masyarakat.

Konsep tentang supranatural atau lorong keselamatan tanpa mengikat orang pada nilai-nilai kesucian yang ditentukan dan pada kelompok sosial atau bias juga menawarkan kebijakan dan tehnik yang dapat digunakan orang untuk membebaskan dirinya dari kelompok kelompok dan nilai-nilai kontemporer agama dapat memberinya kebebasan untuk mencapai nilai-nilai yang mentransendensikan tuntutan dari kehadiran social. Jadi, agama adalah bersifat sungguh-sungguh social (Mulia, 2010, hal. 81-83).

Akan tetapi yang terjadi pada kenyataan, persoalan yang menyangkut agama bukan lagi sebagai peneduh kehidupan sosial akan tetapi menjadi pemicu konflik dengan mengatasnamakan agama, pada permasalahan ini yang di persalahkan bukanlah Agama, akan tetapi para penganutnya yang kurang menginternalisasi keberadaan toleransi beragama pada penganut agama lain, oleh karena itu timbullah sikap radikalisme.

Sebagai sebuah contoh, di Aceh bentokan antar kubu menyebabkan seorang tewas dan sebuah gereja hangus dibakar ratusan orang. Bentrokan dipicu sengketa ijin mendirikan bangunan gereja di kawasan tersebut. Kerusuhan pecah setelah massa yang terdiri dari sekitar 600 orang membakar sebuah gereja Protestan dan bergerak ke gereja kedua. Demikian keterangan Kepala Kepolisian Aceh Husein Hamidi kepada wartawan Di sana mereka dihadang sekelompok warga Kristen yang sudah siap siaga bersama polisi dan militer.

Indonesia dan dunia kita telah banyak digegerkan adanya terorisme dan radikalisme yang mengatasnamakan kepentingan agama. Islam dan jihad menjadi isu yang tetap hangat dalam perbincangan berbagai forum. Yang terbaru, tragedi itu kini dialami oleh saudara kita di Lahore, Pakistan. Ledakan di Taman Gulshane-Iqbal itu ditengarai adanya gesekan antar umat beragama (Radar Kudus 22 April 2016).

\section{Bentuk Toleransi Beragama pada Komunitas Lintas Agama dan Kepercayaan di Pantura (Tali Akrab)}

Setelah mengetahui bagaimana bagaimana makna toleransi sebenarnya, selanjutnya akan kita pelajaribagaimana Toleransi Multi Agama pada Komunitas Lintas Agama dan kepercayaan di Pantura atau lebih dikenal denga sebutan Tali akrab.

Pada komunitas yang di rintis Muhammad Rosyid dkk. yakni komunitas lintas agama di Pantura, dalam komunitas tersebut berbagai agama berkumpul mulai dari agama legal seperti Islam, Kristen, Hindu, Budha, Konghucu,maupun non legal seperti Ahmadiyah, Agama Baha'i, selain itu komunitas ini juga merangkul kaum 
Samin. Diadakannya lintas agama ini tak lain adalah sebagai wujud toleransi dalam beragama. Dengan berbagai perbedaan agama kita dapat bersahabat dan hidup berdampingan.

Adapun acara yang dibuat dalam komunitas tersebut adalah semacam sharing, dialog, dan diskusi, seperti yang diadakan di Kudus (Mei 2014) yang diadakan dibalai budaya untuk membahas sunan Kudus dan sejarah Kota Kretek. Tentu hal ini tidak menyalahi berbagai aturan, baik aturan yang dibuat pemerintah maupun aturan yang dibuat agama kita masing-masing. Karena yang di perbincangkan dalam forum tersebut adalah seputar tema dalam dialog/ diskusi tersebut.

Berikut beberapa acara yang pernah penulis ikuti dalam Komunitas Lintas Agama di Pantura (Tali Akrab) diantaranya adalah sebgai berikut :

Pertama, Mendialogkan Ahmadiyah, bertempat di Masjid Ahmadiyah Semarang, pada acara tersebut tema yang di bahas mengenai keberadaan Ahmadiyah di Indonesia, sehingga dalam forum tersebut kami dapat menegtauhui seluk beluk dari Ahmadiyah yang sempat gempar beberapa waktu lalu. Acara dialog bersama Ahmadiyah ini peneliti ikuti di Masjid Pusat Ahmadiyah Semarang pada tahun 2014.

Kedua, Mendialogkan keberadaan agama Budha, bertempat di Vihara Damma dipha Colo pada tanggal 15-16 desember tahun 2014, pada acara tersebut membahas mengenai seluk beluk agama Budha, keberadaan mereka di lingkungan yang berbeda agama, toleransi agama Budha pada daerah tersebut juga menilik perhatian pemerintah pada penganut agama Budha, mulai dari pendidikan, tempat ibadah, kesejahteraan, sampai pada pemakaman.

Ketiga, menghadiri pentas seni pada hari kenaikan Isa Al-Masih di Hotel Gripta Kudus. Acara ini peneliti ikuti pada tahun 2015, pada acara tersebut umat Kristen melakukan pentas seni dan berdo'a bersama, hal itu hanya dilakukan oleh umat Kristen saja, sedangkan dari umat lain hanya sebagai tamu dan menghadiri acara tersebut.

Keempat, mendialogkan umat Baha'i di Indonesia, bertempat di kediaman Moh. Rosyid. Acara yang terselenggara tahun 2016 tersebut terdapat dialog dari umat Baha’i dan diskusi bersama mahasiswa STAIN Kudus.

Kelima, dialog antar umat beragama, bertempat di Rutan Kudus. Pada acara tersebut terdapat dialog para tahanan dengan berbagai pemuka agama (yang menghadiri Islam, Kristen, Hindu, Budha) dari Komunitas Lintas Agama. Dialog ini dilaksanakan secara interaktif dari berbagai pemuka agama bersama beberapa tahanan. Pada dialog interaktif yang peneliti ikuti tahanan di rutan ini ternyata begitu banyak permasalahan yang dihadapi oleh para tahanan terkait aqidah dalam keberagamaan mereka masing-masing.

Keenam, berdialog tentang antisipasi kebakaran dan sekte Kristen Advent pada Rumah makan How Jek pada tanggal 30 april 2016. Adapun acara yang tedapat 
pada forum tersebut merupakan sosialisasi untuk mengantisipasi kebakaran yang disampaikan oleh pihak pemadam kebakaran, pada sesi kedua adalah pembahasan mengenai salah satu sekte yang terdapat pada agama Kristen yaitu aliran Advent yang di sampaikan oleh pendeta Advent sendiri. Melalui diskusi dialog ini tentu sebelumnya penulis belum tau apa itu Kristen Advent, ternyata Kristen advent ini merupakan salah satu aliran yang ada dalam Kristen yang mempunyai ciri khas pengikutnya tidak memakan hewan berkaki empat, melainkan vegetarian.

Acara dialog dan diskusi yang penulis sebutkan diatas merupakan beberapa acara yang terdapat pada Komunitas Lintas Agama. Acara tersebut diikuti dari berbagai agama dan aliran di Indonesia, baik yang diakui di Indonesia (Islam, Kristen, Hindu, Budha dan Konghucu) maupun yang di permasalahkan (Ahmadiyah, Samin dan Baha'i), oleh karena itu komunitas ini di sebut komunitas lintas agama, karena berbagai agama berkumpul menjadi satu tanpa saling memandang remeh, akan tetapi pada posisi yang seharusnya, yaitu bersahabat.

Hal tersebut menurut peneliti sangatlah berincome baik bagi umat muslim maupun umat-umat lain untuk melaksanakan kedamaian beragama, seperti halnya dalam perbincangan peneliti dengan pendeta Haryanto. Beliau memaparkan kebahagiaannya sebab dapat berkumpul dengan teman di berbagai aliran dengan kedamaian tanpa kecurigaan atau kebencian. Selain itu pada sesi dialog yang dilaksanakan di rumah makan How Jek seorang pendeta yang bernama pendeta Oktov juga sempat memaparkan keberuntungannya dalam mengikuti komunitas tali akrab tersebut. Sebab, melalui komunitas tersebut pengetahuan kita bukan hanya pada lingkup agama kita sendiri, melainkan juga agama-agama lain, nasib keberadaaanya di Indonesia, serta penumbuhan sikap saling bertoleransi.

Memang dalam perkumpulan ini awalnya secara keseluruhan belum terlalu mengenal satu sama lain, tapi setidaknya ada komunikasi dan saling sapa antar satu sama lain. Kedekatan yang terjadi berawal dari diskusi yang terjadi, sharing, perbandingan, itu hal yang biasa, akan tetapi mampu terjalin hubungan baik. Acara tersebut merupakan salah satu wadah untuk berkumpulnya seluruh agama dan aliran tanpa harus mempermasalahkan persoalan agama dalam satu Negara, atau saling mengusik dan menjatuhkan antara satu agama dengan agama yang lain, sebab kefanatikan dalam kepercayaan yang ada dalam diri kita masing-masing, sedangkan toleransi berada pada kehidupan bermasyarakat kita.

Wujud toleransi antar umat beragama pada Komunitas Lintas Agama di Pantura atau Tali Akrab ini adalah saling mengerti dan memahami satu agama dengan agama yang lain, bukan sikap Primordialisme (membanggakan apa yang dimiliki), Etnosentrisme (mengukur budaya atau hal lain dengan apa yang dimiliki), kemudian terdapat sikap inklusif pada yang lain hal seperti inilah yang menghambat persatuan. Jadi dapat kita simpulkan, bahwa dalam perbedaan di perlukan sebuah toleransi dari nurani kita untuk mewujudkan kebersamaan, cinta tanah air dan terwujudlah Bhineka Tunggal Ika yang sebenarnya. Sehingga dengan adanya komunitas pemersatu perbedaan memang sangatlah dibutuhkan dan salah satu 
cara bagi kita untuk bersahabat dalam perbedaan. Seperti halnya komunitas lintas agama di Pantura, sebagaimana yang dijelaskan sebelumnya, dapat menjadi salah satu alternatif dalam mewujudkan toleransi antara satu agama dengan agama lain, karena kita mengenalnya dan kita bisa bersahabat dengan mereka dalam semua perbedaan dan keanekaragaman yang dianugerahkan Tuhan kepada kita.

\section{Komunitas sebagai Perantara Bertoleransi}

Dalam menanamkan jiwa toleransi multi agama sebagai penangkis radikalisme, kita dapat melaksakan kegiatan seperti pembahasan sebelumnya seperti membuat sebuah Komunitas Lintas Agama atau Lintas Agama dan Budaya di lingkungan kita sendiri. Namun, yang perlu digarisbawahi bahwa hal terpenting bukanlah Komunitasnya, karena Komunitas hanya sebagai perantara. Walau demikian tetap saja sebuah Komunitas merupakan sarana pendukung suksesnya dalam penginternalisasian jiwa Toleransi, berikut hal terpenting yang perlu tetanam pada diri setiap Individu mengenai Multi Agama, diantaranya adalah sebagai berikut :

\section{Hak Kebebasan Memilih Agama}

Manusia adalah mahluk ciptaan Tuhan berkewajiban mengabdi kepadaNya untuk mencapai kebahagiaan hidup di dunia dan akhirat. Sejalan dengan peradaban manusia, maka kehidupan beragama tentu mengalami perkembangan yang diwarnai dengan sering terjadinya persinggungan antar pemeluk agama yang beragama itu (Lopa, 1996, hal. 84). Dalam mewujudkan kehidupan beragama di dunia berjalan aman dan tertib, maka PBB sebagai badan dunia mengatur hak dan kebebasan manusia untuk memilih agama dan keyakinan yang dikehendakinya sesuai dengan UDHR pasal 18 yang berbunyi :

Setiaporang berhak untuk bebas berpikir, bertobat dan beragama; hak ini meliputi kebebasan berganti agama atau kepercayaannya dalam bentuk beribadat dan menepatinya, baik sendiri maupun dilakukan bersama-sama denganorang lain, baik di tempat umum maupun tersendiri.

Dalam Al-qur'an surah Al-baqoroh ayat 256, yang berbunyi :

"tidak ada paksaan untuk (memasuki) agama (islam); sesungguhnya telah jelas jalan yang benar daripada jalan yang sesat. Karena itu barang siapa yang ingkar kepada Thaghut dan beriman kepada Allah, maka sesungguhnya ia telah berpegang kepada buhul tali yang amat kuat yang tidaka akan putus. Dan Allah Maha Mendengar lagi Maha mengetahui”.

Sehingga dapat kita ambil kesimpulan bahwa kebebasan individu dalam beragama sangat di hormati (Lopa, 1996, hal. 143).

\section{Nasionalisme dalam beragama}

Memahami Indonesia yang terbentang dari sabang sampai merauke beserta dinamikanya dalam perspektif sejarah memunculkan informasi yang sangat bermanfaat bagi generasi masa kini dan masa mendatang. 
Mengenal Indonesia dalam aspek agama dengan kaca pandang sejarah diharapkan memunculkan sikap toleran diimbangi dengan nasionalisme setiap generasi untuk mewujudkan kerukunan Intern dan lintas agama (Rosyid, 2015, hal. 12). Hubungan antara agama dan Negara dalam konteks Indonesia ternyata menjadi perbincangan yang penting di dalam duskursus keagamaan khususnya agama Islam dan keindonesiaan. Meskipun, para kiai, persoalan relasi agama dan Negara bukan merupakan problem yang sangat penting dan mendasar, sebagaimana bagi kaum modernis, hal itu tidak berarti bahwa mereka sama sekali tidak memilki pemahaman yang menarik tentang relasi antara keduanya.

Sebagai contoh, salah satu diantara panitia sembilan yang merumuskan pancasila adalah KH. A. Wahid Hasyim, salah satu tokoh NU. Di tetapkannya pancasila dan UUD 1945 sebagai dasar Negara telah diterima secara tulus oleh para kiai. Bahkan keputusan itu sudah menjadi ketetapan dalam Muktamar NU ke 11 di Banjarmasin. Hal tersebut membuktikan, bahwa Nasionalisme dan beragama dapat terwujud.

\section{Simpulan}

Bedasarkan Pembahasan diatas dapat disimpulkan bahwa dalam perbedaan di perlukan sebuah toleransi dari nurani kita untuk mewujudkan kebersamaan, cinta tanah air dan terwujudlah Bhineka Tunggal Ika yang sebenarnya. Sehingga, dengan adanya komunitas pemersatu perbedaan memang sangatlah dibutuhkan dan salah satu cara bagi kita untuk bersahabat dalam perbedaan. Seperti halnya komunitas lintas agama di Pantura, sebagaimana yang dijelaskan sebelumnya, dapat menjadi salah satu alternatif dalam mewujudkan toleransi antara satu agama dengan agama lain, karena kita mengenalnya dan kita bisa bersahabat dengan mereka dalam semua perbedaan dan keanekaragaman yang dianugerahkan Tuhan kepada kita. 


\section{Referensi}

Lopa, B. (1996). Al-Quran dan Hak-Hak Asasi Manusia. Yogyakarta: PT Dana Bhakti Prima Yasa : Yogyakarta

Hasan, M. I. (2004), Metode Penelitian, Yogyakarta : Pustaka Pelajar.

Moesa, A. M. (2007). Nasionalisme Kiai. PT LKiS Pelangi Aksara : Bantul

Mustaqim, M. (2007), Pendidikan Multikultral Perspektif Pendidikan Islam, Kudus : STAIN Kudus.

Mulia, S. M., Dkk. (2010). Gempa Budaya Virtual. Justisia IAIN Walisongo Semarang : Semarang

Denzin, N. K. \& Lincoln, Y.S. (2009), Hand Book of Qualitative Research, Yogyakarta : Pustaka Pelajar.

Observasi Partisipatoris penulis di Masjid Pusat Ahmadiyah Semarang pada tahun 2014

Observasi Partisipatoris penulis pada Hotel Gripta Kudus pada tahun 2015

Observasi Partisipatoris penulis pada Kediaman Moh. Rosyid pada tahun 2016

Observasi Partisipatoris penulis pada Rumah makan How Jek di Kudus tanggal 30 april 2016

Observasi Partisipatoris penulis pada Vihara Damma Dipha di Colo pada15-16 desember 2014

Radar Kudus, 22 April 2016

Rosyid, M. (2015). Agama Baha’i. Yogyakarta: Pustaka Pelajar.

Rosyid, M. (2015). Esai-Esai Toleransi. Yogyakarta: Tim Idea Press. 